\title{
Modelling Equation of Contraction Coefficient (Cc) and Discharge Coefficient (Cd) for Flow under Sluice Gate Using Cubic Baffle Block and Sill
}

\author{
Sunik Sunik \\ Department of Civil Engineering, Faculty of Engineering, Widya Karya Catholic University, \\ Jl. Bondowoso 2 Malang 65115, Jawa Timur, Indonesia.
}

\begin{abstract}
:
One of devices in hydraulic structures that used for flow control was sluice gate. Flow under sluice gate in variation of open gate $(\mathrm{a}=1,2,3,4 \mathrm{~cm})$ and variation of discharge $(\mathrm{Q})$ rise the contraction coefficient $(\mathrm{Cc})$ and discharge coefficient $(\mathrm{Cd})$. Fiberglass prototype model as horizontal channel was used for this experimental research with dimension: length $(\mathrm{L})=9 \mathrm{~m}$, width $(B)=50 \mathrm{~cm}$ and using sluice gate installed on it, height $(\mathrm{h})=80 \mathrm{~cm}$, thick $(\mathrm{t})=1 \mathrm{~cm}$, width $(\mathrm{b})=50 \mathrm{~cm}$. Two models of baffle block as cubic using end sill (code K1, 16 running, no sill, $\mathrm{s}_{1}=2 \mathrm{~cm}$; code $\mathrm{K} 2,16$ running, $\mathrm{s}_{1}=2 \mathrm{~cm}, \mathrm{~s}_{2}=2.7 \mathrm{~cm}$ ) with different dimension $\left(\mathrm{Bb}_{1}=0.7 \mathrm{~cm}, \mathrm{Bb}_{2}=1.4 \mathrm{~cm}\right)$ installed as three row, specified location $25 \mathrm{~cm}$ after sluice gate. During each running test with variation open gate and discharge, the velocity (v) and height of flow (h) were measured then Froude number, contraction coefficient $(\mathrm{Cc})$ and discharge coefficient (Cd) were analyzed. The result showed that cubic baffle block model K2 (used sill $2 \mathrm{~cm}$ and $2.7 \mathrm{~cm}, \mathrm{Fr}=0.09-0.88$ ) gives the better performance modelling of $\mathrm{Cc}$ and $\mathrm{Cd}$ in term of the initial Froude number with $\mathrm{R}^{2}=0.9152(\mathrm{Cc})$ and $\mathrm{R}^{2}=0.9053$ (Cd). It was concluded that using three rows configuration of cubic baffle block with $\mathrm{K} 2$ model $(1.4 \mathrm{~cm} \times 1.4 \mathrm{~cm} \times 1.4 \mathrm{~cm})$ gave better model than $\mathrm{K} 1$.
\end{abstract}

Keyword: Cubic Baffle Block, Sill, Froude number, Contraction Coefficient, Discharge Coefficient

\section{INTRODUCTION}

Flow under sluice gate (as one of a channel infrastructure component usually installation in irrigation network) while operated with certain open gate will raise contraction coefficient $(\mathrm{Cc})$, followed by discharge coefficient $(\mathrm{Cd})$ and rise hydraulic jump. To reach the stable condition and reduce the energy cause by hydraulic jump, it used baffle block (Chaudry, 2008) that placed in front of the gate with certain distance and or using sill (Raju, et al, 1980) that placed at the lower end of channel (tailwater/downstream depth) as additional structure. Baffle block have a function to reduce velocity and energy when a hydraulic jump occurs. Sill have a function to increasing the water level at the downstream or end of the channel. Sunik (2001) had research about Cc and Cd for flow under sluice gate in free flow condition. The contraction coefficient under sluice gates on flat beds for both free flow and submerged conditions based on the principle of momentum conservation has studied by Gilles Belaud (1943). Sluice gate discharge coefficient is an involved function of geometric and hydraulic parameters stated by Swami (1990) while he developed discharge coefficient equations for free and submerged flows. It is related to upstream depth and gate opening for free flow whereas it depends on tail-water depth for submerged flow. The discharge coefficient of sluice gate depend on sill shape and sill height stated by Adulaziz A. Allahamid (1997). Various characteristics of a vertical sluice gate in a rectangular flatbed channel investigated by $\mathrm{Fu}$ Yen (2001)

The ratio of actual discharge to the theoretical discharge delivered by the structure defined as discharge coefficient (Cd). The ratio of water depth at vena contracta, $y_{2}$ to gate opening defined as contraction coefficient (Cc). In this study, flow behavior under sluice gate is simulated, contraction coefficient $(\mathrm{Cc})$ and discharge coefficient $(\mathrm{Cd})$ was analyze.

Henderson (1966) derived equation to compute $\mathrm{Cd}$ for free flow as:

$$
C_{d}=\frac{C_{c}}{\sqrt{1+\eta}}
$$

where: $\eta=(\mathrm{Cc} . \mathrm{b}) / \mathrm{y}_{1}, \mathrm{Cc}=\mathrm{y}_{2} / \mathrm{b}$.

This research aims to analyze equation modelling of $\mathrm{Cc}$ and $\mathrm{Cd}$ with two models of cubic baffle block $(\mathrm{K} 1, \mathrm{~K} 2)$ that located in front of sluice gate in a channel using prototype model channel test.

\section{EXPERIMENTAL WORK}

These experimental was development from earlier research (Sunik, 2001). Configuration about experiment laboratory explain below as seen in Figure 1. Water depth (y) and velocity (v) measurement for each running implemented in 12 section.

The prototype model as horizontal channel made from fiberglass (used for trial running flow, with dimension as width $(B)=50 \mathrm{~cm}$, length $(\mathrm{L})=9 \mathrm{~m})$. Sluice gate placed on it with dimension, width $(\mathrm{b})=50 \mathrm{~cm}$, thick $(\mathrm{t})=1 \mathrm{~cm}$, height $(\mathrm{h})=80$ $\mathrm{cm}$, using added device (cubic baffle block and sill) as energy dissipator, present in Figure 1. 


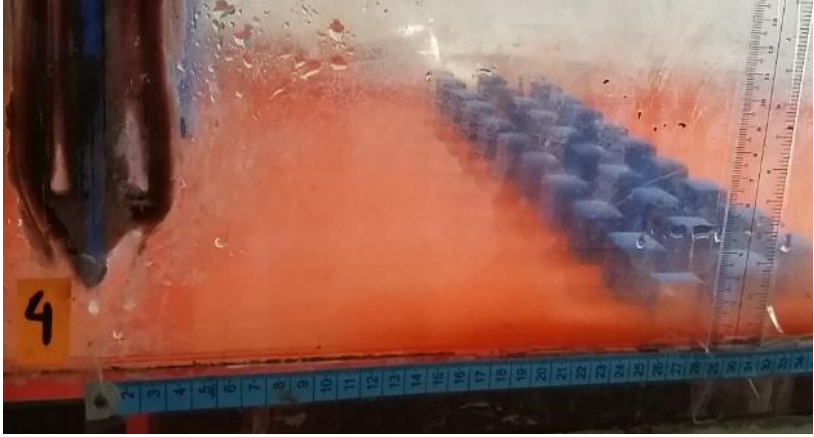

Fig 1. Cubic baffle block configuration in front of sluice gate (source: primary data)

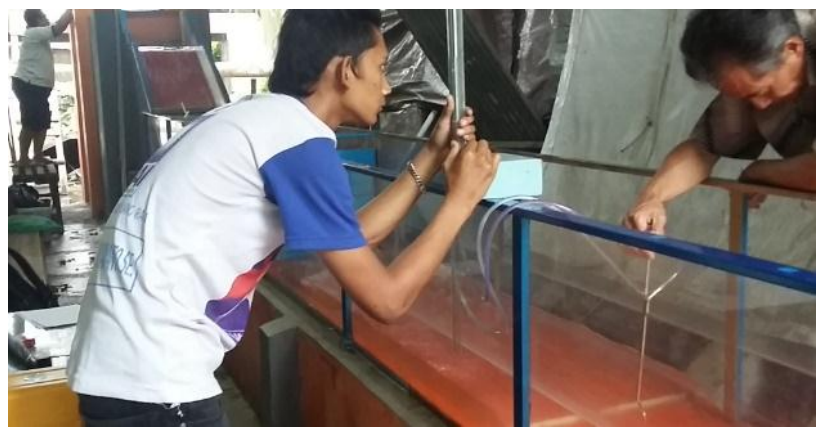

Fig 2. Water depth and velocity measurement for 12 section (source: primary data)

Table 1: Configuration dimension of cubic baffle block

\begin{tabular}{|c|c|c|c|c|c|c|}
\hline No & $\begin{array}{c}\text { Model } \\
\text { Baffle } \\
\text { Block }\end{array}$ & Type & Run & $\begin{array}{r}\left(\mathrm{b}_{\mathrm{b}}\right) \\
\mathrm{mm}\end{array}$ & $\begin{array}{r}\left(\mathrm{l}_{\mathrm{b}}\right) \\
\mathrm{mm}\end{array}$ & $\begin{array}{c}\left(\mathrm{h}_{\mathrm{b}}\right) \\
\mathrm{mm}\end{array}$ \\
\hline \multirow{2}{*}{1} & $\mathrm{~K}$ & $\mathrm{~K} 1$ & 16 & 7 & 7 & 7 \\
\cline { 2 - 7 } & $\mathrm{K} 2$ & 16 & 14 & 14 & 14 \\
\hline
\end{tabular}

Source: primary data

Table 2: Configuration dimension of sill for the channel

\begin{tabular}{|c|c|c|c|c|}
\hline No & $\begin{array}{c}\text { Model } \\
\text { Baffle } \\
\text { Block }\end{array}$ & Type & Sill type & $\begin{array}{c}(\mathrm{hs}) \\
(\mathrm{cm})\end{array}$ \\
\hline \multirow{2}{*}{1} & $\mathrm{~K}$ & $\mathrm{~K} 1$ & $\mathrm{~s}_{1}, \mathrm{~s}_{2}$ & no sill; 2 \\
\cline { 3 - 5 } & $\mathrm{K} 2$ & $\mathrm{~s}_{2}, \mathrm{~s}_{3}$ & 2 and 2.7 \\
\hline
\end{tabular}

Source: primary data

Configuration dimension of cubic $(\mathrm{K})$ baffle block type of $\mathrm{K} 1$, width $\left(b_{b 1}\right)=7 \mathrm{~mm}$, length $\left(l_{b 1}\right)=7 \mathrm{~mm}$ and height $\left(\mathrm{h}_{\mathrm{b} 1}\right)=7$ $\mathrm{mm}$; type of $\mathrm{K} 2$, width $\left(\mathrm{b}_{\mathrm{b} 2}\right)=14 \mathrm{~mm}$, length $\left(\mathrm{l}_{\mathrm{b} 2}\right)=14 \mathrm{~mm}$ and height $\left(\mathrm{h}_{\mathrm{b} 2}\right)=14 \mathrm{~mm}$. Sill placed in downstream channel with dimension width $\left(\mathrm{b}_{\mathrm{s} 1}\right)=50 \mathrm{~cm}$, thick $\left(\mathrm{t}_{\mathrm{s}}\right)=1 \mathrm{~cm}$, height $\left(\mathrm{h}_{\mathrm{s} 1}, \mathrm{~h}_{\mathrm{s} 2}\right.$, $\mathrm{h}_{\mathrm{s} 3}=$ no sill, $\left.2 \mathrm{~cm}, 2.7 \mathrm{~cm}\right)$. Variation of open gate $(\mathrm{a})=1 \mathrm{~cm}$, $2 \mathrm{~cm}, 3 \mathrm{~cm}, 4 \mathrm{~cm}$.
Table 1 present two set of experiments test with a total of 32 run, using cubic baffle block in cross sectional (three rows, each baffle block made from fiberglass) mixing with configuration of sill that placed in downstream as present in Table 2. Figure 2 present each run, simulation of flow was trial till configuration of hydraulic jump was perform in stabilized to the desire location of $25 \mathrm{~cm}$ downstream from the sluice gate. Measurement was done in 12 section of flow (1-upstream, 2under the gate, 3-before baffle block installation, 4-before the jump (the initial depth, $\mathrm{y}_{1}$ ), 5-above the baffle block, 6-the end baffle block, 7-after the jump (sequent depth, $\mathrm{y}_{2}$ ), 8-end of roller, 9-end of jump, 10-3/4 length before the sill, 11-1/2 length before the sill, 12-1/4 near the sill) for the depth (y) of water. Measured for each section consist of left, middle and right part that each part measure in above, middle and bottom of height flow (one section consist of nine measured). In the same procedure, the local velocity (v) for 12 section was measured. The Froude number (Fr) affected by value of velocity and the depth.

Relation between Froude number, $\mathrm{Fr}$ and contraction coefficient $(\mathrm{Cc})$ and discharge coefficient $(\mathrm{Cd})$ was analyze using regression method (Nawari, 2007) to know influence of Fr against to $\mathrm{Cc}$ and $\mathrm{Cd}$. Determination coefficient value was criteria that showed the variable against to the response (Sembiring, 1995) as:

$$
\mathrm{R}^{2}=1-(\Sigma \mathrm{JKG} / \Sigma \mathrm{JKT})
$$

where:

$\Sigma \mathrm{JKG}=$ sum of error square

$\Sigma \mathrm{JKT}=$ total sum of squares

\section{RESULTS}

\subsection{Contraction Coefficient (Cc)}

Correlation result between Froude number and contraction coefficient model K1, K2 show in Figure 3; value of Cc present in Table 3 and Table 4.

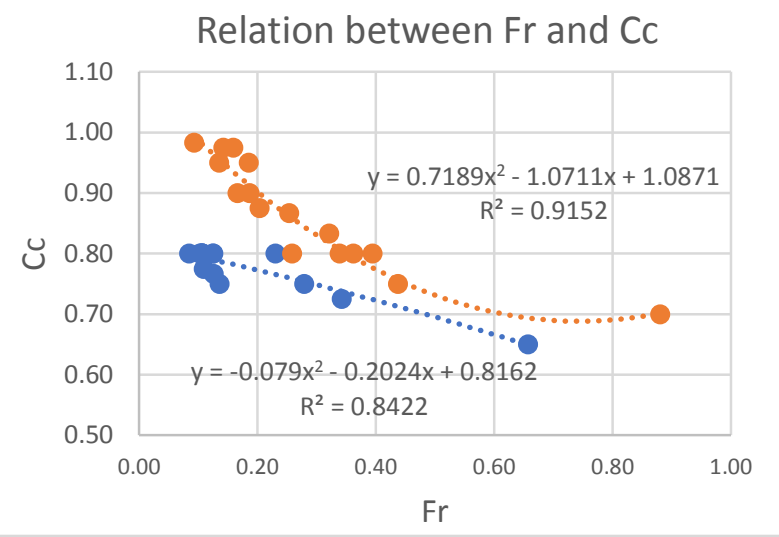

Fig.3 Contraction coefficient (Cc) for cubic baffle block model K1, K2 (source: analysis data) 
Table 3: Value of Contraction Coefficient (Cc) for K1 model

\begin{tabular}{|c|c|c|c|c|c|c|}
\hline No & Run & $\begin{array}{c}\text { Q } \\
(\mathbf{I} / \mathbf{s})\end{array}$ & $\begin{array}{c}\text { a } \\
(\mathbf{c m})\end{array}$ & $\begin{array}{c}\text { sill } \\
(\mathbf{c m})\end{array}$ & Fr & Cc \\
\hline 1 & 17 & 14.65 & 3 & 2 & 0.23 & 0.80 \\
\hline 2 & 18 & 11.01 & 2 & 2 & 0.34 & 0.73 \\
\hline 3 & 20 & 10.15 & 2 & 2 & 0.28 & 0.75 \\
\hline 4 & 22 & 6.44 & 1 & 2 & 0.66 & 0.65 \\
\hline 5 & 25 & 3.94 & 1 & - & 0.13 & 0.80 \\
\hline 6 & 27 & 6.76 & 2 & - & 0.08 & 0.80 \\
\hline 7 & 29 & 9.67 & 3 & - & 0.13 & 0.77 \\
\hline 8 & 31 & 12.92 & 4 & - & 0.11 & 0.80 \\
\hline 9 & 48 & 7.84 & 1 & - & 0.11 & 0.80 \\
\hline 10 & 49 & 4.66 & 1 & - & 0.14 & 0.75 \\
\hline 11 & 50 & 12.27 & 2 & - & 0.10 & 0.80 \\
\hline 12 & 51 & 7.51 & 2 & - & 0.11 & 0.80 \\
\hline 13 & 52 & 16.31 & 3 & - & 0.10 & 0.80 \\
\hline 14 & 53 & 11.01 & 3 & - & 0.11 & 0.80 \\
\hline 15 & 54 & 20.71 & 4 & - & 0.11 & 0.78 \\
\hline 16 & 55 & 14.38 & 4 & - & 0.12 & 0.80 \\
\hline
\end{tabular}

Source: primary data and analysis

Table 4: Value of Contraction Coefficient (Cc) for $\mathrm{K} 2$ model

\begin{tabular}{|c|c|c|c|c|c|c|}
\hline No & Run & $\begin{array}{c}\text { Q } \\
(\mathbf{l} / \mathbf{s})\end{array}$ & $\begin{array}{c}\text { a } \\
(\mathbf{c m})\end{array}$ & $\begin{array}{c}\text { sill } \\
(\mathbf{c m})\end{array}$ & Fr & CC \\
\hline 1 & 56 & 4.663 & 1 & 2 & 0.26 & 0.80 \\
\hline 2 & 57 & 6.862 & 1 & 2 & 0.34 & 0.80 \\
\hline 3 & 58 & 7.507 & 2 & 2 & 0.14 & 0.95 \\
\hline 4 & 59 & 11.13 & 2 & 2 & 0.17 & 0.90 \\
\hline 5 & 60 & 11.13 & 3 & 2 & 0.09 & 0.98 \\
\hline 6 & 61 & 15.47 & 3 & 2 & 0.19 & 0.90 \\
\hline 7 & 62 & 15.47 & 4 & 2 & 0.14 & 0.98 \\
\hline 8 & 63 & 19.51 & 4 & 2 & 0.19 & 0.95 \\
\hline 9 & 64 & 6.862 & 1 & 2.7 & 0.39 & 0.80 \\
\hline 10 & 65 & 8.625 & 1 & 2.7 & 0.88 & 0.70 \\
\hline 11 & 66 & 11.13 & 2 & 2.7 & 0.36 & 0.80 \\
\hline 12 & 67 & 13.05 & 2 & 2.7 & 0.44 & 0.75 \\
\hline 13 & 68 & 14.38 & 3 & 2.7 & 0.25 & 0.87 \\
\hline 14 & 69 & 17.31 & 3 & 2.7 & 0.32 & 0.83 \\
\hline 15 & 70 & 19.51 & 4 & 2.7 & 0.16 & 0.98 \\
\hline 16 & 71 & 21.33 & 4 & 2.7 & 0.20 & 0.88 \\
\hline
\end{tabular}

Source: primary data and analysis

\subsection{Discharge Coefficient (Cd)}

Correlation result between Froude number and discharge coefficient model K1, K2 show in Figure 3; value of Cc present in Table 5 and Table 6.

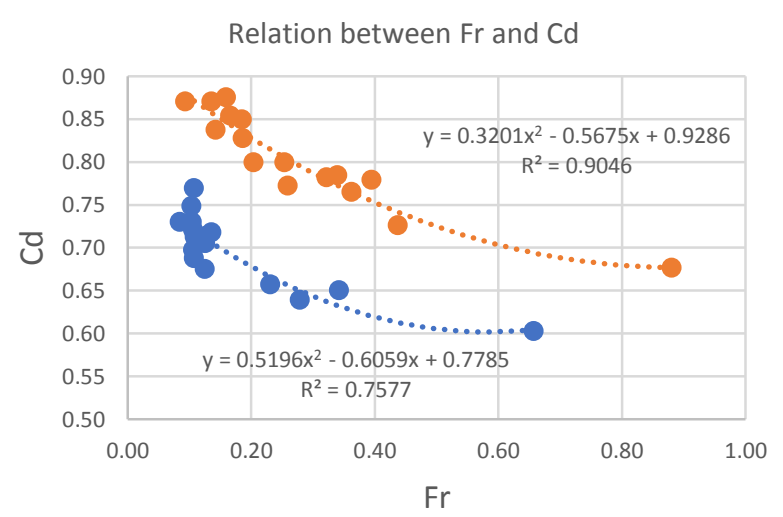

Fig.4 Discharge coefficient (Cc) for cubic baffle block model $\mathrm{K} 1, \mathrm{~K} 2$ (source: analysis data)

Table 5: Value of Discharge Coefficient $(\mathrm{Cd})$ for $\mathrm{K} 1$ model

\begin{tabular}{|c|c|r|c|c|c|c|}
\hline No & Run & $\begin{array}{c}\text { Q } \\
\text { (I/s) }\end{array}$ & $\begin{array}{c}\text { a } \\
\text { (cm) }\end{array}$ & $\begin{array}{c}\text { sill } \\
\text { (cm) }\end{array}$ & Fr & Cd \\
\hline 1 & 17 & 14.65 & 3 & 2 & 0.23 & 0.66 \\
\hline 2 & 18 & 11.01 & 2 & 2 & 0.34 & 0.65 \\
\hline 3 & 20 & 10.15 & 2 & 2 & 0.28 & 0.64 \\
\hline 4 & 22 & 6.44 & 1 & 2 & 0.66 & 0.60 \\
\hline 5 & 25 & 3.94 & 1 & - & 0.13 & 0.71 \\
\hline 6 & 27 & 6.76 & 2 & - & 0.08 & 0.73 \\
\hline 7 & 29 & 9.67 & 3 & - & 0.13 & 0.71 \\
\hline 8 & 31 & 12.92 & 4 & - & 0.11 & 0.69 \\
\hline 9 & 48 & 7.84 & 1 & - & 0.11 & 0.77 \\
\hline 10 & 49 & 4.66 & 1 & - & 0.14 & 0.72 \\
\hline 11 & 50 & 12.27 & 2 & - & 0.10 & 0.73 \\
\hline 12 & 51 & 7.51 & 2 & - & 0.11 & 0.72 \\
\hline 13 & 52 & 16.31 & 3 & - & 0.10 & 0.75 \\
\hline 14 & 53 & 11.01 & 3 & - & 0.11 & 0.70 \\
\hline 15 & 54 & 20.71 & 4 & - & 0.11 & 0.71 \\
\hline 16 & 55 & 14.38 & 4 & - & 0.12 & 0.68 \\
\hline
\end{tabular}

Source: primary data and analysis 
Table 6: Value of Discharge Coefficient (Cd) for K2 model

\begin{tabular}{|c|c|r|c|c|c|c|}
\hline No & Run & $\begin{array}{c}\text { Q } \\
(\mathbf{l} / \mathbf{s})\end{array}$ & $\begin{array}{c}\text { a } \\
(\mathbf{c m})\end{array}$ & $\begin{array}{c}\text { sill } \\
(\mathbf{c m})\end{array}$ & Fr & Cd \\
\hline 1 & 56 & 4.66 & 1 & 2 & 0.26 & 0.77 \\
\hline 2 & 57 & 6.86 & 1 & 2 & 0.34 & 0.78 \\
\hline 3 & 58 & 7.51 & 2 & 2 & 0.14 & 0.87 \\
\hline 4 & 59 & 11.13 & 2 & 2 & 0.17 & 0.85 \\
\hline 5 & 60 & 11.13 & 3 & 2 & 0.09 & 0.87 \\
\hline 6 & 61 & 15.47 & 3 & 2 & 0.19 & 0.83 \\
\hline 7 & 62 & 15.47 & 4 & 2 & 0.14 & 0.84 \\
\hline 8 & 63 & 19.51 & 4 & 2 & 0.19 & 0.85 \\
\hline 9 & 64 & 6.86 & 1 & 2.7 & 0.39 & 0.78 \\
\hline 10 & 65 & 8.63 & 1 & 2.7 & 0.88 & 0.68 \\
\hline 11 & 66 & 11.13 & 2 & 2.7 & 0.36 & 0.77 \\
\hline 12 & 67 & 13.05 & 2 & 2.7 & 0.44 & 0.73 \\
\hline 13 & 68 & 14.38 & 3 & 2.7 & 0.25 & 0.80 \\
\hline 14 & 69 & 17.31 & 3 & 2.7 & 0.32 & 0.78 \\
\hline 15 & 70 & 19.51 & 4 & 2.7 & 0.16 & 0.88 \\
\hline 16 & 71 & 21.33 & 4 & 2.7 & 0.20 & 0.80 \\
\hline
\end{tabular}

Source: primary data and analysis

\section{DISCUSSION}

\subsection{Contraction Coefficient $(\mathrm{Cc})$}

Based on $\mathrm{R}^{2}$ value, the better performance showed by cubic baffle block type $\mathrm{K} 2$ that used sill $2 \mathrm{~cm}$ and $2.7 \mathrm{~cm}$ at the channel, with $\mathrm{Fr}=0.09-0.88, \mathrm{Cc}=0.75-0.95$, the equation present as:

$\mathrm{y}=0.7189 \mathrm{x}^{2}-1.0711 \mathrm{x}+1.0871, \mathrm{R}^{2}$ value $=0.9152$

The value $\mathrm{R}^{2}$ close to 1 for determination coefficient. It means that a strong relation between value $\mathrm{Fr}$ to contraction coefficient had present (value of Cc influenced by Fr, while Fr depend on velocity (v) and depth of water (y)). Adding device i.e sill at the channel influenced velocity of flow, affected to $\mathrm{Cc}$ value.

\subsection{Discharge Coefficient $(\mathrm{Cd})$}

Based on $\mathrm{R}^{2}$ value, the better performance showed by cubic baffle block type $\mathrm{K} 2$ that used sill $2 \mathrm{~cm}$ and $2.7 \mathrm{~cm}$ at the channel, with $\mathrm{Fr}=0.09-0.88, \mathrm{Cd}=0.68-0.88$, the equation present as:

$$
y=0.3201 x^{2}-0.5675 x+0.9286, R^{2} \text { value }=0.9046
$$

The value $\mathrm{R}^{2}$ close to 1 for determination coefficient. It means that a strong relation between value Fr to discharge coefficient had present (value of $\mathrm{Cd}$ influenced by $\mathrm{Cc}$ ).

\section{CONCLUSION}

Configuration of baffle block (depend on number of baffle blocks, spacing between adjacent blocks, width of the block, dimension of block) paired with matched sill placement will gave better performance of $\mathrm{Cc}$ and $\mathrm{Cd}(<1)$ while sluice gate operate with variation open gate.

It concluded that cubic baffle block model $\mathrm{K} 2(1.4 \mathrm{~cm})$ combine with two model of sill $(2$ and $2.7 \mathrm{~cm})$ gave better performance for $\mathrm{Cc}$ and Cd value (determination coefficient $\mathrm{R}^{2}$ $=0.9152$ and $\left.\mathrm{R}^{2}=0.9046\right)$ than model $\mathrm{K} 1$ (no sill and $2 \mathrm{~cm}$ ).

\section{REFERENCES}

[1] Abdulaziz A. Allahamid, 1997, Coefficient of Discharge of Sluice Gate, J. King. Saud University, Eng. Science paper-1, $11: 33-48$

[2] Jung-Fu Yen, 2001, Hydraulic Characteristics and Discharge Control of Sluice Gate- Journal of the Chinese Institute of Engineers, 24(3): 301-310

[3] Gilles Belaud, 1943, Calculation of Contraction Coefficient Under Sluice Gate and Application to Discharge Measurement, Journal of Hydraulic Engineering (ASCE), 135(12): 1086-1091

[4] Henderson,F.M. 1966, Open Channel Flow, MacMillan

[5] K.G. Ranga Raju, M.K. Kitaal, M.S.Verma \& V.R. Ganeshan,, 1980, Analysis of Flow Over Baffle Blocks and End Sills, Journal of Hydraulic Research, Vol. 18, Issue 3, pp. 227-241.

[6] Nawari, 2007, Regression Analysis using MS Excel and SPSS, PT Elex Media Komputindo. Jakarta.

[7] M. Hanif Chaudhry, 2008, Open Channel Flow, Second Edition, University of South Carolina, Springer

[8] Sembiring, 1995, Regression Analysis. ITB, Bandung.

[9] Sunik, 2001, Simulation Operation Sluice Gate for Secondary Channel Using Model Test Physic, Master Thesis, Brawijaya University.

[10] Swami , P. K., 1990, Sluice Gate Discharge Equation, Journal Irrigation and Drainage Engineering (ASCE), 118(1):5660. 